\title{
Notes on the vocalizations of Andean Solitaire (Myadestes ralloides)
}

Peter Boesman

In the following we briefly analyze and compare voice of the different races of Andean Solitaire (Myadestes ralloides). We also try to quantify the extent of any vocal differences using the criteria proposed by Tobias et al. (2010), as a support for taxonomic review. We have made use of sound recordings available on-line from Xeno Canto (XC).

A comparison of song per race, illustrated with sonograms:

M. r. plumbeiceps (W \& C Andes of Colombia and W Ecuador)

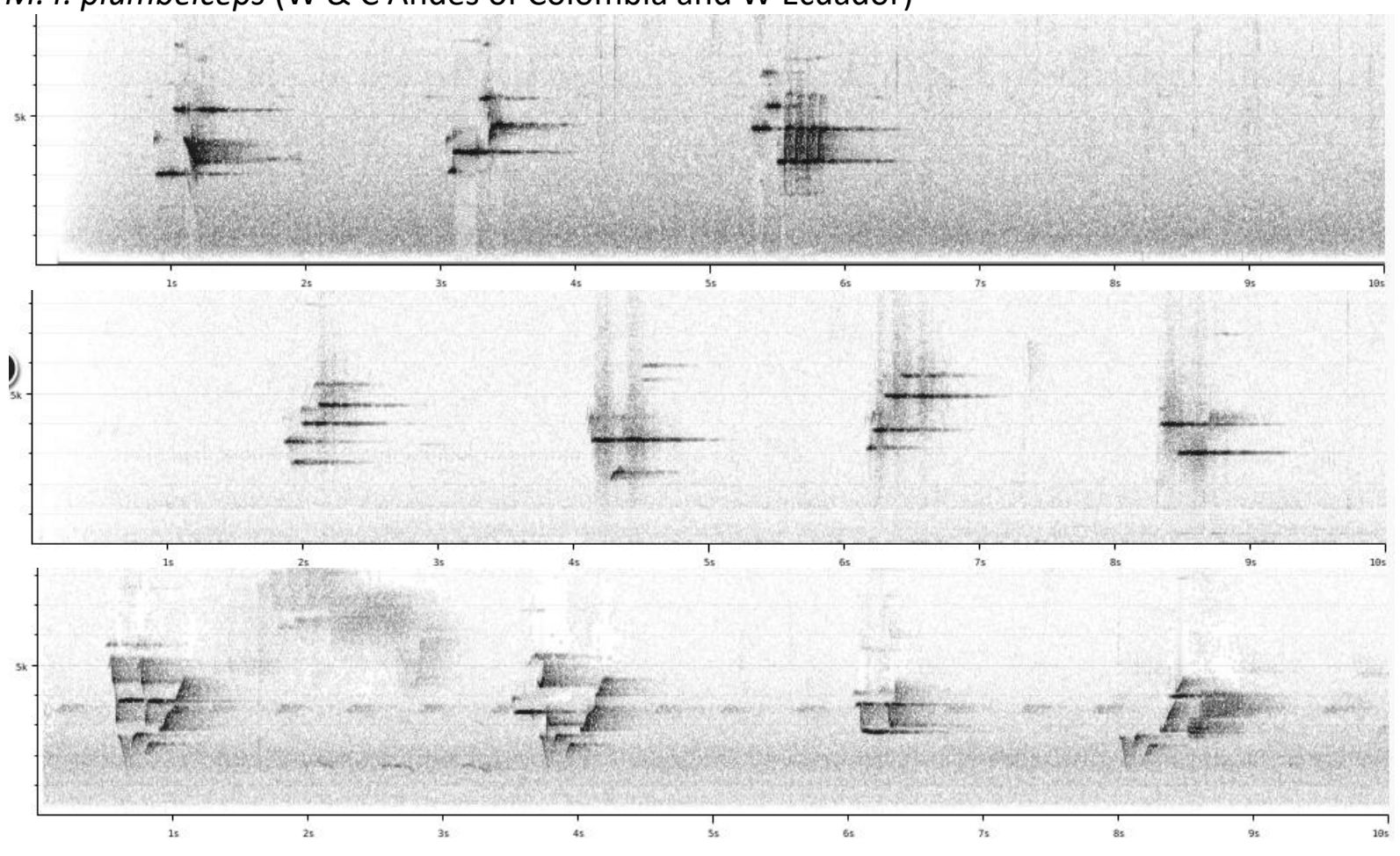

M. r. candelae (NC Colombia (Magdalena Valley))

No definite recordings available. One recording from RNA Reinita Cielo Azul, San Vicente de Chucuri, Santander either this species or venezuelensis.

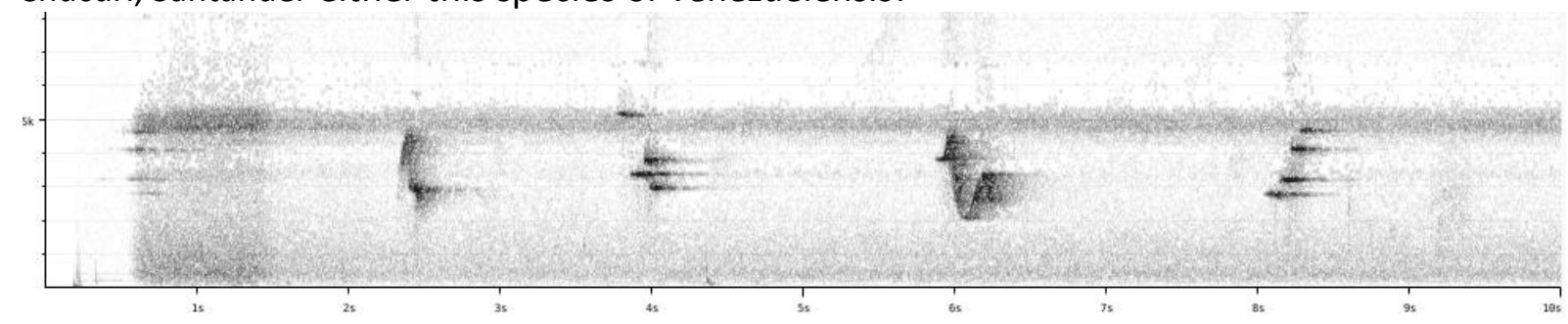


HANDBOOK OF THE

BIRD PIg ORNITHORLD WGICAL NOTES

M. r. venezuelensis ( $N$ \& W Venezuela S in E Andes to N Peru ( $N$ of R Marañón)) Venezuela
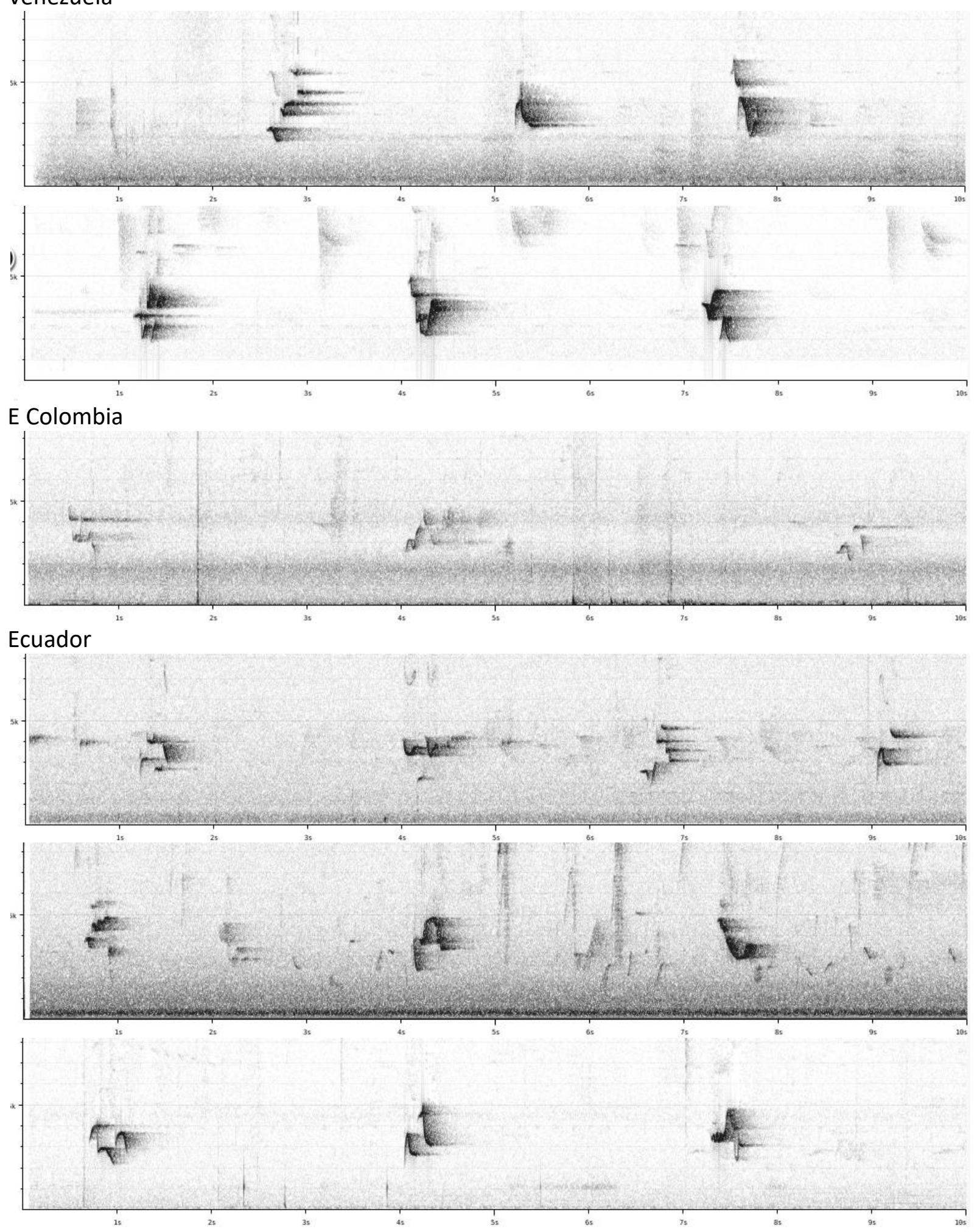

2 


\section{HANDBOOK OF THE \\ BIRDSPFTHE WORLD}

\section{ORNITHOLOGICAL NOTES}

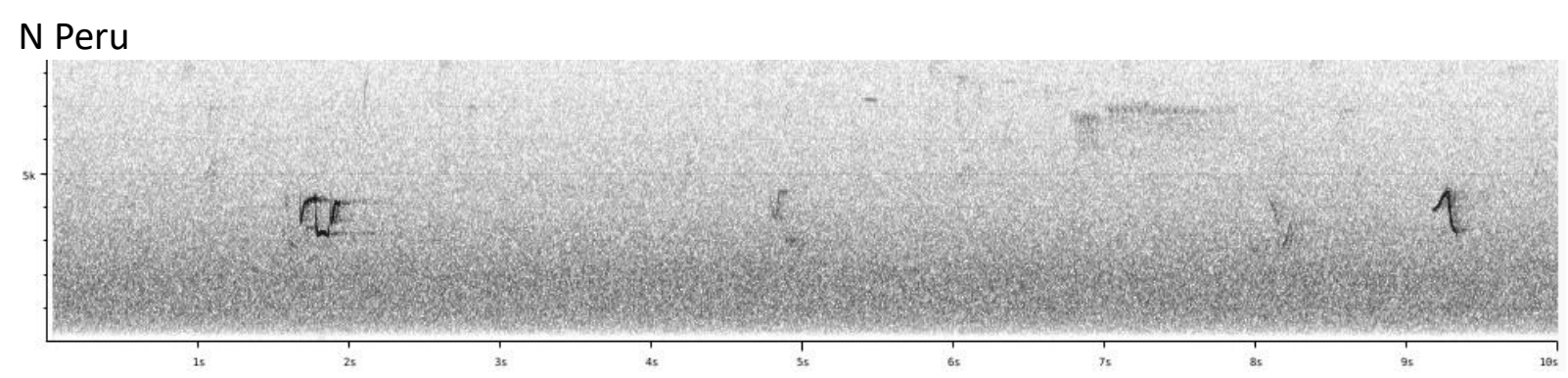

M. r. ralloides Peru (S of R Marañón, $\mathrm{S}$ to W \& C Bolivia (S to Chuquisaca))

Peru
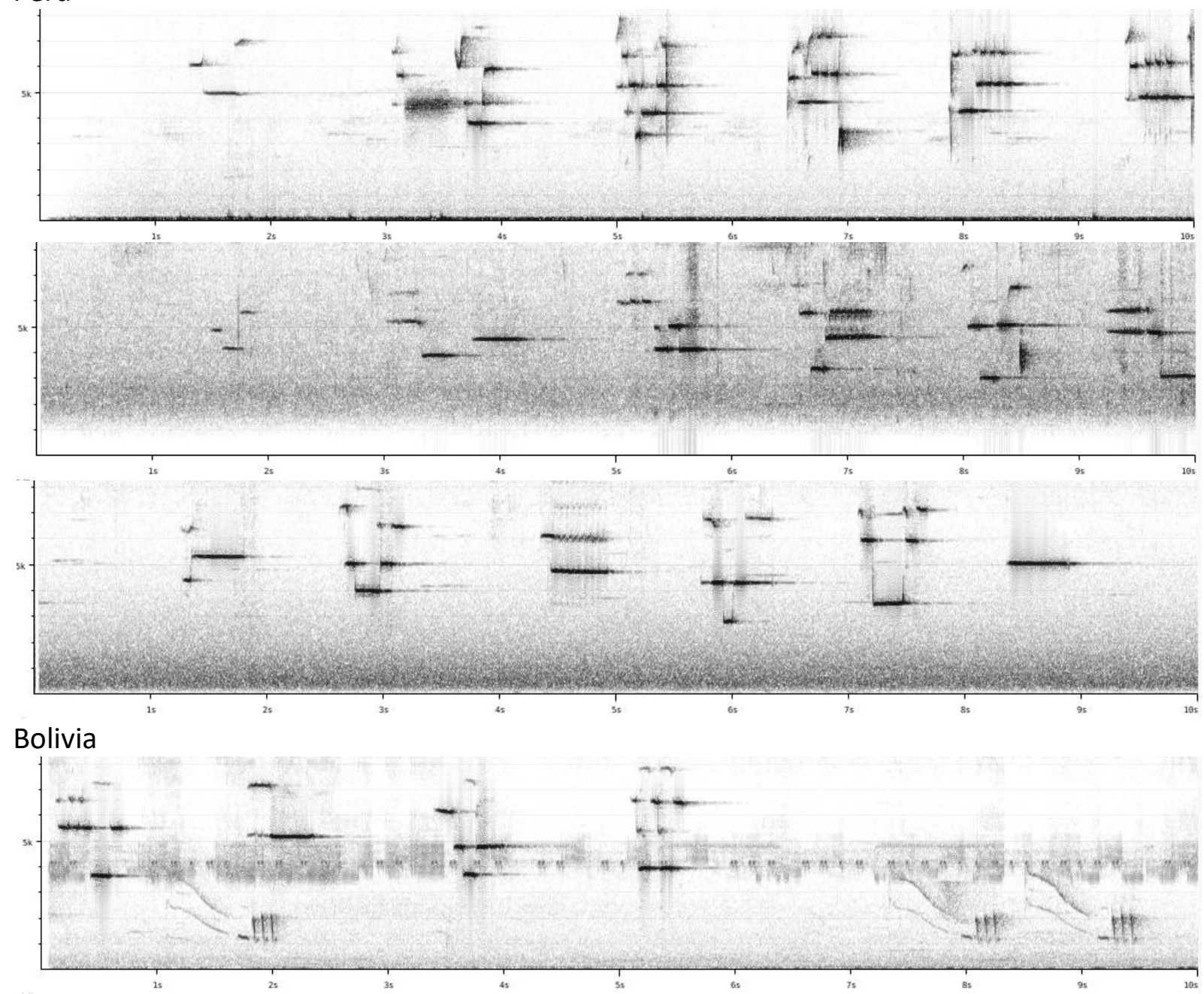

It is quite clear that there are three vocal groups:

NW Andean group (candelae): song consists of short strophes separated by long pauses. Each strophe has a few short notes which typically are not slurred. It would seem that some notes are given simultaneously, suggesting both sides of the syrinx oscillate independently. Number of notes per phrase about 3-6. 

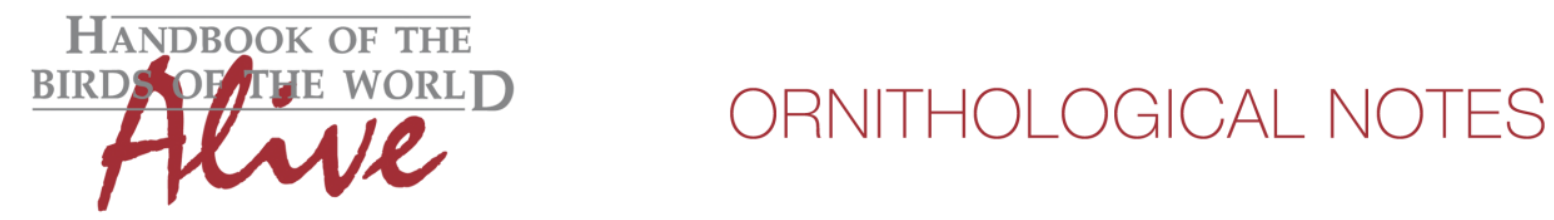

NE Andean group (venezuelensis): song consists of short strophes separated by long pauses. Each strophe has very few notes which typically are slurred, sometimes alternated with phrases more similar to NW Andean group. In comparison with NW Andean group, average number of notes per phrase lower, average length of notes longer, average frequency range per note higher.

S Andean group (nominate): song consists of short phrases which are separated by short pauses, resulting in an almost continuous song. Phrases are a mix of very short notes, and long notes at constant pitch. At least some notes are given simultaneously suggesting both sides of the syrinx oscillate independently. Max. frequency much higher than previous two groups ( $c 7-8 \mathrm{kHz}$ vs c 5-6kHz for NW Andean group and c 4-5.5kHz for NE Andean group).

Vocal differences are thus substantial.

$S$ Andean group is most distinctive, mainly differing by much shorter pauses between strophes (2), higher frequency of notes (2), longer notes at flat pitch (2) etc. Total vocal score about 4 .

NE Andean group differs from NW Andean group by lower average number of notes per phrase (1-2), longer average length of notes (1-2), higher average frequency range per note (2) and note shapes (many slurred vs. unslurred)(1). Total vocal score about 3.

Situation of race candelae unclear.

Calls may also differ, but there aren't many recordings available and context not always clear (contact call, alarm call, distress call, begging call,...).

This note was finalized on 7th October 2016, using sound recordings available on-line at that moment. We would like to thank in particular the many sound recordists who placed their recordings for this species on XC.

\section{References}

Tobias, J.A., Seddon, N., Spottiswoode, C.N., Pilgrim, J.D., Fishpool, L.D.C. \& Collar, N.J. (2010). Quantitative criteria for species delimitation. Ibis 152(4): 724-746.

\section{Recommended citation}

Boesman, P. (2016). Notes on the vocalizations of Andean Solitaire (Myadestes ralloides). HBW Alive Ornithological Note 435. In: Handbook of the Birds of the World Alive. Lynx Edicions, Barcelona. (retrieved from http://www.hbw.com/node/1284484 on 8 December 2016). 